УДК 316.4

Ситник O.І., к.п.н., доцент

Сільвестрова О.Ю., к.ф.н., доцент

Луцький національний технічний університет

\title{
ТЕОРЕТИЧНІ ЗАСАДИ ДЕРЖАВНОЇ СОЦАЛЬНОЇ ПОЛІТИКИ В ТРАНСФОРМАЦІЙНІЙ ЕКОНОМІЦІ
}

Досліджено еволюцію і наступність підходів до розуміння соціальної політики. Визначена сутність державної соціальної політики. Здійснено грунтовний аналіз основних підходів та проведено їх класифікацію. Визначені об'єкти та суб'єкти соціальної політики. Обгрунтовані основні завдання державної соціальної політики.

Ключові слова: політика, соціальна політика, об’єкт соціальної політики, суб'єкт соціальної політики, завдання соціальної політики.

Сытник О.І. , Сильвестрова О.Ю.

\section{ТЕОРЕТИЧЕСКИЕ ОСНОВАНИЯ ГОСУДАРСТВЕННОЙ СОЦИАЛЬНОЙ ПОЛИТИКИ В ТРАНСФОРМАЦИОННОЙ ЭКОНОМИКЕ}

\begin{abstract}
Исследовано эволюцию и поступательность подходов к пониманию социальной политики. Определена сущность государственной социальной политики. Осуществлен детальный анализ основных подходов и проведено их классификацию. Определены объекты и субъекты социальной политики. Обоснованы основные задачи государственной социальной политики.

Ключевые слова: политика, социальная политика, объект социальной политики, субъект социальной политики, задачи социальной политики.
\end{abstract}

Sytnyk O., Sil'vestrova O.

\section{THEORETICAL PRINCIPLES OF THE STATE SOCIAL POLICY IN TRANSFORMATION ECONOMY}

The evolution and continuity of approaches to the understanding of social policy are explored. The essence of the state social policy is defined. A thorough analysis of the main approaches was carried out and their classification was performed. The objects and subjects of social policy were defined. The main tasks of the state social policy are substantiated.

Key words: politics, social policy, object of social policy, subject of social policy, tasks of social policy.

Постановка проблеми у загальному вигляді i iï зв'язок із важливими науковими та практичними завданнями. Україна декларується як соціальна держава, а людина, її життя і здоров’я, честь і гідність, недоторканість і безпека визнаються як найвища соціальна цінність. Увага до людини, її прав і свобод та їх гарантії визначають зміст і спрямованість діяльності держави. Враховуючи, що людина є основою державної політики, це не може не відбитися на формуванні сучасної моделі соціальної політики. Сьогодні ми спостерігаємо загострення проблем соціального спрямування, серед яких: істотний розрив між рівнем доходів багатих і бідних верств населення, невідповідність оплати праці іï реальній продуктивності, криза солідарної системи пенсійного забезпечення, проблеми трудової міграції тощо. Соціальні питання в пріоритеті передвиборчих програмах політичних партій і лідерів держави.

Глобалізаційні зрушення і питання внутрішньої політики держави зумовлюють необхідність і доцільність розробки нової моделі соціальної політики, яка б адекватно реагувала б на виклики сьогодення.

У даному контексті важливим $є$ уточнення теоретичних аспектів соціальної політики, iї категоріального апарату, методологічних засад.

Аналіз останніх досліджень, у яких започатковано вирішення проблеми. Увага до соціальної політики як центральної ранки державної політики є значною. Серед 
науковців, які займаються різноманітними питаннями вивчення соціальної політики варто відмітити праці таких як: Р. Баркер, Л. Безтелесна, Ю. Бондаренко, Н. Волгін, О. Воронін, Б. Гаєвський, Н. Галіцина, Т. Ганслі, І. Григорієва, О. Давидюк, О. Іванова, В. Копіцин, А. Колот, О. Крентовська, І. Лавриненко, Г. Лопушняк, Е. Лобінова, У. Лоренц, В. Мелянюк, О. Новікова, І. Садова, Т. Семінога, В. Скуратівський, В. Співок, П. Спікер, П. Шевчук, О. Яременко та інші.

В працях даних авторів розглянуті питання сутності категоріального апарату соціальної політики, соціальних відносин, реалізації соціальної політики.

Проте залишаються питання теоретичної чіткості розуміння феномену «соціальна політика», визначення пріоритетності соціальної політики серед інших складових державної політики.

Цілі статті. Аналіз основних теоретичних підходів до розуміння феномену «соціальна політика», реалізація ії вихідних принципів.

Виклад основного матеріалу дослідження 3 повним обгрунтуванням отриманих наукових результатів. Категорія «соціальна політика» широко використовується в соціальних науках, теорії і практиці державного управління, в офіційних державних документах. Поняття «соціальна політика» в науковий обіг було запроваджено у Франції теоретиком утопічного соціалізму Ш. Фур'є, який наголошував на обов'язках держави надавати своїм громадянам певні соціальні гарантії.

Відсутність чіткої визначеності поняття «соціальна політика» створює певні методологічні труднощі в ії розумінні. В свою чергу відсутність базового теоретичного розуміння соціальної політики перешкоджає специфіці ії практичної реалізації.

3 огляду на це основним завданням вважаємо детальне опрацювання наявних у наукових дослідженнях підходів до розуміння соціальної політики і формування на основі власних висновків перспективного розуміння соціальної політики.

Можна виділити кілька підстав для класифікації основних підходів щодо розуміння соціальної політики. Розширимо класифікацію, яка була запропонована Л.І. Безтелесною, Г.М. Юрчик [1, с.142-143].

Таблиця 1.

Зміст та основні підходи до визначення соціальної політики

\begin{tabular}{|c|c|c|}
\hline Підстави & Авторське визначення соціальної політики & Автор/джерело \\
\hline 1 & 2 & 3 \\
\hline \multirow{4}{*}{ 兽 } & $\begin{array}{l}\text { «... діяльність та принципи суспільства, які формують спосіб, за } \\
\text { допомогою якого воно втручається та регулює відносини між } \\
\text { індивідами, групами, громадами, соціальними закладами» }\end{array}$ & $\begin{array}{l}\text { Р. Баркер, } 1994 \\
{[2, \text { с.38] }}\end{array}$ \\
\hline & $\begin{array}{l}\text { Система цілеспрямованої діяльності суб’єктів соціально- } \\
\text { політичного життя, сукупність принципів, норм, правил, рішень, } \\
\text { дій, спрямованих на забезпечення ефективного оптимального } \\
\text { функціонування та розвитку процесів соціального буття }\end{array}$ & $\begin{array}{l}\text { В. Скуратівський, О. } \\
\text { Палій, Е. Лібонова, } \\
1997 \\
{[3, \text { с.342] }}\end{array}$ \\
\hline & $\begin{array}{l}\text {... цілеспрямована діяльність держави та інших суб’єктів у галузі } \\
\text { формування умов життя населення та міжособистісних відносин }\end{array}$ & $\begin{array}{l}\text { А. Райкевич, } 1997 \text { р. [4, } \\
\text { c.7] }\end{array}$ \\
\hline & $\begin{array}{l}\text { «... діяльність держави щодо збалансування розвитку } \\
\text { суспільства, забезпечення державного правління, соціального } \\
\text { захисту населення, створення сприятливих умов для існування } \\
\text { індивідів і соціальних спільнот» }\end{array}$ & $\begin{array}{l}\text { В. Піча, Н. Хома } \\
{[5, \text { с.114] }}\end{array}$ \\
\hline
\end{tabular}




\begin{tabular}{|c|c|c|}
\hline 1 & 2 & 3 \\
\hline \multirow{2}{*}{. } & $\begin{array}{l}\text { «це діяльність державних та громадських інститутів, суспільних } \\
\text { груп та окремих осіб (суб’єктів соціальної політики), спрямована } \\
\text { на реалізацію природних прав людини, що забезпечують її } \\
\text { життєдіяльність та розвиток як соціальної істоти при } \\
\text { беззастережному дотриманні її громадянських прав і свобод» }\end{array}$ & $\begin{array}{l}\text { О. Сергієнко, } 2002 \\
{[6, \text { с.36] }}\end{array}$ \\
\hline & $\begin{array}{l}\text { В широкому розумінні - «цілеспрямована діяльність держави та } \\
\text { інших політичних інститутів і громадських об’єднань, } \\
\text { спрямована на вдосконалення соціальної сфери»; у вузькому } \\
\text { розумінні «діяльність суб’єктів соціальної політики, спрямована } \\
\text { на захист груп населення, неспроможних до самозахисту та } \\
\text { самозабезпечення, організація соціальних служб» }\end{array}$ & $\begin{array}{l}\text { О. Яременко, } 2006 \\
{[7, \text { с.27] }}\end{array}$ \\
\hline \multirow{4}{*}{ 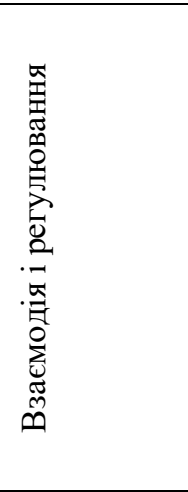 } & $\begin{array}{l}\text { «Система взаємодії державної влади, що постійно оновлюється, } \\
\text { недержавних структур, самої особистості щодо забезпечення та } \\
\text { розвитку людини» }\end{array}$ & $\begin{array}{l}\text { А. Сіленко, } 2003 \\
{[8, \text { с.120] }}\end{array}$ \\
\hline & $\begin{array}{l}\text { «... це один із напрямів суспільного регулювання, спрямований } \\
\text { на зменшення суперечливостей у всіх сферах» }\end{array}$ & $\begin{array}{l}\text { Г. Осадча, } 1999 \\
{[9, \text { с. } 145]}\end{array}$ \\
\hline & $\begin{array}{l}\text { «... як складова частина внутрішньої політики держави, що } \\
\text { регулює стосунки в суспільстві в інтересах та через інтереси } \\
\text { основних соціальних груп населення» }\end{array}$ & $\begin{array}{l}\text { С. Тетерський, } 2000 \\
{[10, \text { с.103] }}\end{array}$ \\
\hline & $\begin{array}{l}\text { «один із елементів повної моделі державного регулювання } \\
\text { економіки, конкретна форма, інструмент державної економічної } \\
\text { політики (разом 3 } 3 \text { фінансовою, кредитно-грошовою, } \\
\text { зовнішньоекономічною та 225н..)» }\end{array}$ & $\begin{array}{l}\text { Л. Дмитриченко, } 2001 \\
{[11, \text { с.53] }}\end{array}$ \\
\hline \multirow{3}{*}{ 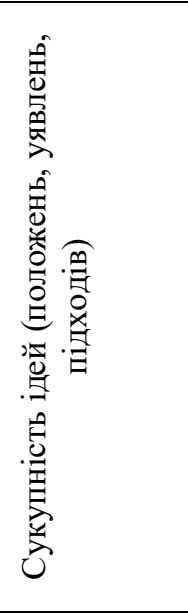 } & $\begin{array}{l}\text { «сукупність науково сформованих ідей, положень та } \\
\text { концептуальних підходів (як довготермінового, стратегічного, } \\
\text { так і короткотермінового, тактичного характеру, що поєднується } \\
\text { iз системою конкретних дій, заходів, важелів, стимулів і } \\
\text { механізмів, за допомогою яких практично регулюються соціальні } \\
\text { процеси)» }\end{array}$ & $\begin{array}{l}\text { В. Мандибура, } \\
2000 \\
{[12, \text { с.22] }}\end{array}$ \\
\hline & $\begin{array}{l}\text { «... сукупність ідеологічних уявлень суспільства і держави про } \\
\text { цілі соціального розвитку та діяльність щодо досягнення } \\
\text { соціальних показників, які відповідають цим цілям» }\end{array}$ & $\begin{array}{l}\text { Е. Холостова, } \\
2001 \\
{[12, \text { с.21] }}\end{array}$ \\
\hline & $\begin{array}{l}\text { «... система ідеологічних уявлень та ціле направлену діяльність } \\
\text { держави, громадсько-політичних інститутів, підприємств та } \\
\text { окремих громадян на соціальну сферу для забезпечення } \\
\text { безконфліктності соціальних відносин, урегульованості } \\
\text { соціальних процесів та задоволення соціальних потреб в цілях } \\
\text { соціального (людського) розвитку» }\end{array}$ & $\begin{array}{l}\text { А. Безтелесна, } \\
\text { Г. Юрчин, } \\
2013 \\
{[1, \text { с.146] }}\end{array}$ \\
\hline \multirow{2}{*}{ 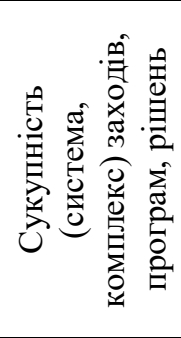 } & $\begin{array}{l}\text { «... в організаційному відношенні соціальна політика становить } \\
\text { систему принципів, заходів і методів задоволення за допомогою } \\
\text { політики основних потреб людини, соціальних прошарків, усього } \\
\text { населення країни» }\end{array}$ & $\begin{array}{l}\text { Б. Гаєвський, } \\
1999 \\
{[13, \text { с.164] }}\end{array}$ \\
\hline & $\begin{array}{l}\text { Комплекс заходів, що здійснюються державними інститутами та } \\
\text { недержавними суб'єктами } 3 \text { метою виявлення, задоволення та } \\
\text { узгодження потреб та інтересів громадян, соціальних груп, } \\
\text { територіальних громад }\end{array}$ & $\begin{array}{l}\text { А. Крупнік, } \\
2002 \\
{[14, \text { с.9] }}\end{array}$ \\
\hline \multirow[t]{2}{*}{ 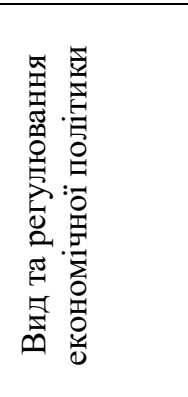 } & $\begin{array}{l}\text { «по-перше, як один із видів саме економічної політики; по-друге, } \\
\text { як цілісну автономну систему в системі економічної політики, що } \\
\text { дозволяє виділити мінімум два напрямки у цій системі: перший, } \\
\text { пов’язаний із забезпеченням ефективності реалізації цілей інших } \\
\text { видів економічної політики, другий із забезпеченням соціального } \\
\text { захисту тих верств населення, індивідів, які потребують саме } \\
\text { захисту, підтримки з боку суспільства у прямому розумінні цього } \\
\text { слова» }\end{array}$ & $\begin{array}{l}\text { Монографія за заг. ред. } \\
\text { Д. Лук'яненка } \\
{[16, \text { с.97] }}\end{array}$ \\
\hline & «... сфера переважно економічних & $\begin{array}{l}\text { Т.Перглер, } 1998 \\
\text { [17] }\end{array}$ \\
\hline
\end{tabular}


Проведений аналіз підходів до визначення соціальної політики показує, що найбільш вживаним є діяльнісний підхід. Проте слід заважити, що політика, соціальна політика зокрема, не лише зводиться до діяльності (уряду, держави, партій тощо). Суттєвим є і ідеологічні чинники, які заповнюють діяльнісний підхід.

Автори термінологічно-понятійного словника «Соціальна політика і соціальна робота» зазначають, що державна соціальна політика - це «ідея, втілена в конкретний документ, затверджений законодавчою владою, який $є$ керівництвом до дії i, у свою чергу, результатом політичного процесу» $[18$, с.386].

Проте, соціальна політика це не лише ідея, але і діяльність, і процес, і результат. Тому доцільно під державою соціальною політикою розуміти, «... діяльність органів державної влади та органів місцевого самоврядування, а також діяльність партій, громадських об’єднань, державних установ і організацій, що регламентується відповідними законодавчими та нормативними актами, відображає суспільний устрій і регулює взаємовідносини в суспільстві для забезпечення гідного рівня життя населення та визначається їх цілями й інтересами» [19, с.28].

Проаналізувавши основні підходи до розуміння соціальної політики, визначивши іiі сутність важливо акцентувати увагу на баченні об'єкта і суб'єкта соціальної політики. Аналіз наукової літератури показує відсутність єдиного бачення об'єкта і суб'єкта соціальної політики.

Варто погодитися з думкою О. Яременка, що соціальна політики є передусім, регулятором соціальних процесів і соціальних перетворень й охоплює такі основні складові: «... суб'єкти, які розглядають і впроваджують соціальні програми, об'єкти, які підлягають регулюванню, канали впливу суб'єктів на об’єкти» [7, с.23].

Суб'єкти соціальної політики мають складну структуру. До них належить людина, держава, суспільство, соціальні спільності та інститути, політичні партії, громадські організації, асоціації громадян, колективи, різноманітні фонди, що здійснюють свою діяльність у різноманітних формах як у межах інституціональних структур, так і на громадських самодіяльних засадах.

Об’єктивною основою багатосуб'єктності в здійсненні соціальної політики $є$ різноманітність соціальних відносин у суспільстві, які створюють суб'єктивні умови для багатства, різного прояву способів реалізації соціального потенціалу людини та інших суб'єктів соціальної політики.

Складніше 3 визначенням об'єкта соціальної політики. До об'єктів соціальної політики дослідники відносять соціальний захист, соціальні служби, соціальне забезпечення тощо.

3 поміж підходів щодо об’єктів соціальної політики найбільш точнішим є підхід запропонований О. Яременком. До об’єктів він відносить соціальну структуру (вивчення соціального складу, усталеності, стабільності організації, режиму керування, системи мотивації, символіки, традицій, способу життя), соціальні умови праці і життя, соціальні відносини, соціальні норми [7, с.36].

Значна увага в науковій літературі приділяється визначенню основних завдань (напрямів) соціальної політики. Завдання соціальної політики чітко виписані у чинному законодавстві України. Основними засадами внутрішньої політики в соціальній сфері визначено:

- забезпечення гарантованих Конституцією України прав і свобод громадян на основі впровадження європейських стандартів соціального захисту, підвищення якості соціальних послуг;

- надання громадянам упродовж всього життя соціальних гарантій на основі вдосконалення системи соціальних стандартів і пільг;

- досягнення ефективного демографічного розвитку;

- поліпшення соціального захисту дітей, утворення духовно і фізично здорової, матеріально забезпеченої та соціально благополучної сім'ї; 
- сприяння молоді в реалізації творчих можливостей та ініціатив, залучення іiі до активної участі в соціальному, економічному та гуманітарному розвитку держави;

- забезпечення доступним житлом громадян, насамперед малозабезпечених, iз обмеженими фізичними можливостями, молоді, працівників бюджетної сфери, формування потужного державного замовлення на будівництво соціального житла, відродження доступного іпотечного кредитування;

- трансформацію державної політики у сфері зайнятості та ринку праці, зокрема через розвиток партнерства між роботодавцями і найманими працівниками, власниками підприємств, установ, організацій та професійними спілками;

- подолання бідності і зменшення соціального розшарування, зокрема шляхом само зайнятості населення, розвитку малого та середнього бізнесу, недопущення виникнення заборгованості із заробітної плати на підприємствах, установах, організаціях усіх форм власності;

- забезпечення державних гарантій щодо реалізації соціальних прав працівників підприємств, установ, організацій усіх форм власності;

- забезпечення захисту прав громадян України, які працюють за кордоном та сприяння їх поверненню в Україну;

- поетапне погашення зобов'язань держави за знеціненими заощадженнями громадян;

- удосконалення системи пенсійного забезпечення, створення умов для гідного життя людей похилого віку, стимулювання розвитку недержавної системи пенсійного страхування;

- забезпечення розміру соціальних виплат, які є основним джерелом доходів, на рівні не нижчому за прожитковий мінімум, удосконалення системи підтримки соціально незахищених верств населення;

- подолання бездомності громадян, безпритульності та бездоглядності дітей [20].

Дані засади чітко визначають завдання державної соціальної політики. Ефективність подальших теоретичних узагальнень сутності, змісту, структури, принципів та завдань соціальної політики буде перспективним у напрямі уніфікації різнопланових підходів до даної проблематики.

Висновки. Державну соціальну політику слід розглядати як багаторівневу i багатофункціональну систему, яка зможе забезпечити соціальний та економічний розвиток країни внаслідок активізації людського капіталу та максимальної реалізації його інноваційного потенціалу. Під нею розуміємо діяльність органів державної влади та органів місцевого самоврядування, політичних партій і громадських об'єднань, державних установ і організацій, діяльність яких направлена на забезпечення достойного рівня життя населення.

Головним завданням соціальної політки визначено забезпечення чіткого функціонування всієї системи соціально-політичних інститутів, які є суб’єктами такої політики, здійснення координації, узгоджувальної діяльності різних елементів системи.

\section{Список використаних джерел:}

1. Безтелесна Л.У., Юрчик Г.М. Сутність та складові соціальної політики: теоретичний аспект. Вісник соціально-економічних досліджень. 2013. Вип. 2 (49). ч.2, с.141-147.

2. Баркер Р. Словарь социальной работы. Пер. с англ. Москва, 1994. 345с.

3. Скуратівський В.А., Палій О.М., Лібонова Е.М. Соціальна політика: навч. посіб. Київ; УАДУ, 1997. 364c.

4. Социальна политика. / за ред. А. Райкевича. Москва: Прогресс, 1997. 400с.

5. Піча В.М., Хома Н.М. Політологія: навч. посіб. Київ: Коровелла, 2001. 344c.

6. Сергієнко О. Соціальна політика в сучасному світі та в Україні. Україна: аспекти праці. 2001. №1. С.31-37.

7. Яременко О.О. Соціальна політика: теоретико-методологічні основи дослідження процесів формування та ефективності реалізації: монографія. Київ: Ін-т економіки та прогнозування НАН України; УІСД ім.. О. Яременко, 2006. 480c.

8. Сіленко А. Соціальна політика та ії пріоритети у перехідному суспільстві. Людина і політика. 2003. №1. C.118-128.

9. Осадчая Г.И. Социология социальной сферы. Москва: Союз. 1999. 279с.

10. Тетерский С.В. Введение в социальную работу. Москва: Академический проспект. 2000. 496с.

11. Дмитриченко А.И. Государственное регулирование экономики: методология и теория: монография. Донецк: УкрНТЕК. 2001. 329c. 
12. Мандибура В. Соціальна політика держави та ії складові. Україна: аспекти праці. 2000. №7. С.21-23.

13. Холосова Е.М. Социальная политика: учеб. пособие. Москва: ИНФРА-М, 2001. 204c.

14. Гаєвський Б.А. Сучасна українська політологія. Київ: МАУП, 1999. 265с.

15. Крупнік А.С. Соціально-захисна спрямованість державної соціальної політики в умовах трансформації українського суспільства: монографія. Одеса. 2002. 169c.

16. Стратегія економічного розвитку в умовах глобалізації: монографія / за ред.. Д.Г. Лук'яненка. Київ: КНЕУ, 2001. 538c.

17. Перглер Т.І. Роль соціально-правової держави Німеччини у стабілізації суспільства: автореф. дис.... канд. політ. наук: 23.00.02. Київ, 1998. 20с.

18. Головатий М.Ф., Панасюк М.Б. Соціальна політика і соціальна робота: термінол.-понятійн. слов.: Київ: МАУП, 2005. 560c.

19. Лопушняк Г.С. Державна соціальна політика як передумова економічного розвитку України: монографія. Львів: ЛРІДУ НАДУ, 2011. 372с.

20. Про засади внутрішньої та зовнішньої політики: Закон України від 01.07.2010p. №2411-ІҮ. Дія та оновлення: 08.07.2018p. URL: http: // zakon. rada. gov. ua / laws / show / 2411-17 (дата звернення 28.02.2019).

Рещензент д.е.н., професор Шубалий О.М. 